\title{
PENGELOLAAN DANA DESA DAN ALOKASI DANA DESA DALAM PENINGKATAN KEGIATAN EKONOMI PRODUKTIF DI DESA
}

\author{
Imran Rosman Hambali ${ }^{1)}$, Fitri Hadi Yulia Akib ${ }^{2)}$ \\ Fakultas Ekonomi, Universitas Negeri Gorontalo ${ }^{1), 2)}$
}

\begin{abstract}
ABSTRAK
Tujuan dari penelitian ini adalah untuk menggambarkan bagaimana pengelolaan Dana desa dan Alokasi dana desa yang diberikan oleh pemerintah pusatdan daerah. Metode penelitian yang digunakan adalah penelitian deskriftif dengan pendekatan kualitatif dan menggunakan metode analisis Milles dan Huberman. Berdasarkan hasil penelitian terbukti ampuh mensejahterakan masyarakat. Hal tersebut bisa dilihat dari berbagai capaian yang dilakukan oleh Pemerintah Kabupaten Bone Bolango. Keberhasilan dana desa dalam mensejahterakan masyarakat, membuat pemerintah pusat terus meningkatkan jumlah alokasi anggaran dana desa setiap tahunnya. Anggaran Dana Desa Tahun 2017 Rp. 122.344.494.000. Alokasi dana peruntukkan 30\% untuk biaya operasional Pemerintah Desa dan Badan Permusyawaratan Desa (BPD); 70\% untuk pemberdayaan masyarakat dan penguatan kapasitas Pemerintahan Desa. Fakta membuktikan bahwa Dana Desa mampu menjadi daya ungkit terhadap perekonomian desa untuk berkembang maju dan meningkatkan kesejahteraan masyarakat di kabupaten bone bolango. Metode penelitian yang digunakan adalah penelitian deskriptif dengan pendekatan kualitatif dan menggunakan metode analisis Milles dan Huberman.
\end{abstract}

Kata Kunci : Pengelolaan Dana Desa dan Alokasi Dana Desa ( ADD ), Kegiatan Ekonomi Produktif

\section{PENDAHULUAN}

Dalam implementasi Otonomi Daerah salah satu aspeknya adalah Pengelolaan Keuangan Daerah, karena Pengelolaan Keuangan Daerah merupakan suatu Program Daerah bidang Keuangan untuk mencapai tujuan dan sasaran tertentu serta mengemban misi mewujudkan suatu strategi melalui berbagai kegiatan. Peraturan Pemerintah Nomor 72 Tahun 2005 tentang Desa dimana Penyelenggaraan Urusan Pemerintah Desa yang menjadi Kewenangan Desa didanai dari Anggaran Pendapatan dan Belanja Desa dan Bantuan Pemerintah Desa sesuai dengan surat Menteri Dalam Negeri Nomor: 140/640SJ tanggal 22 Maret 2005 tentang Pedoman Alokasi Dana Desa dari pemerintah Kabupaten kepada Pemerintah Desa, serta Peraturan Menteri Dalam Negeri Nomor 37 tahun 2007 tentang Pedoman Pengelolaan Keuangan Desa.
Desa mempunyai hak untuk memperoleh bagi Hasil Pajak Daerah dan Retribusi Daerah Kabupaten serta bagian dari Dana Perimbangan Keuangan Pusat dan Daerah yang diterima oleh Kabupaten sesuai Peraturan Pemerintah Nomor 72 Tahun 2005 Pasal 68. Perolehan bagian Keuangan Desa dari Kabupaten penyalurannya melalui Kas Desa sesuai dengan pasal 2A Undang-Undang Nomor 34 Tahun 2000 tentang perubahan atas Undang-Undang Nomor 28 Tahun 2009 tentang Pajak dan Retribusi Daerah.

Disatu sisi sesuai amanat UU Nomor 6 Tahun 2014 tentang Desa, desa diberikan kewenangan untuk mengurus tata pemerintahan dan pelaksanaan pembangunan secara mandiri untuk meningkatkan kesejahteraan dan kualitas hidup masyarakat desa. Di samping itu, pemerintah desa diharapkan secara mandiri mengelola pemerintahan dan berbagai sumber daya yang dimilikinya, termasuk di dalamnya 
pengelolaan keuangan dan kekayaan milik desa. Demikian besar peran yang diterima oleh desa, tentunya disertai dengan tanggung jawab yang besar pula. Oleh karena itu pemerintah desa harus bisa menerapkan prinsip akuntabilitas dalam tata pemerintahannya, di mana semua akhir kegiatan penyelenggaraan pemerintahan desa harus dapat dipertanggungjawabkan kepada masyarakat desa sesuai dengan ketentuan.

Dalam perencanaan, penganggaran, dan pelaksanaan, pemerintah desa harus melibatkan masyarakat desa yang direpresentasikan melalui proses pengambilan keputusan dalam musyawarah desa yang difasilitasi oleh Badan Permusyawaratan Desa (BPD). Dengan keterlibatan semua pihak, diharapkan akan dapat dihasilkan program kerja dan kegiatan yang mengakomodasi kepentingan dan kebutuhan masyarakat desa secara inklusif serta sesuai dengan kemampuan yang dimiliki oleh desa tersebut.

Khusus pembangunan dari berbagai sektor yang dimulai dari pembangunan di desa desa yang menitik beratkan pada anggaran ADD, memiliki peranan yang sangat penting dan strategis dalam rangka pembangunan nasional dan peningkatan kegiatan ekonomi suatu daerah. Berdasarkan peraturan daerah tentang Alokasi Dana Desa, rincian penggunaan ADD adalah $30 \%$ untuk pemerintahan desa yang akan digunakan untuk biaya operasional, tunjangan, biaya perjalanan dinas dari pemerintahan desa, sedangkan $70 \%$ penggunaan ADD untuk kegiatan Ekonomi pemberdayaan masyarakat dan penguatan kapasitas pemerintah desa dan dari rincian penggunaan ADD yang akan dilaksanakan nanti perlu adanya pengelolaan yang baik dari pemerintah desa agar dalam pelaksanaannya nanti akan sesuai dengan tujuan dan sasaran ADD.

Pemerintah Provinsi Gorontalo selalu berupaya membenahi dan memberikan berbagai program-program peningkatan kegiatan ekonomi dengan memanfaatkan fasilitas dan sumber - sumber dana bantuan yang diberikan oleh pemerintah pusat dalam hal ini adalah pemanfaatan Alokasi Dana Desa ke wilayah Kabupaten dan Kota yang diharapkan bisa mempercepat laju pembangunan dan peningkatan ekonomi produktif Desa sehingga diharapkan bisa menunjang pembangunan daerah. Untuk itu di perlukan satu gambaran tentang pengelolaan Dana Alokasi desa dengan fokus kajian adalah pengelolaan dana desa di Kabupaten Bone Bolango.

Berdasarkan uraian diatas, maka dalam penelitian ini yang akan di kaji yaitu "Bagaimana Pengelolaan Alokasi Dana Desa dalam menunjang peningkatkan kegiatan ekonomi produktif di desa?"

\section{TINJAUAN PUSTAKA}

\section{A. Konsep Pemerintah Desa}

Desa berdasarkan Undang-Undang 22/ 1999 (Bratakusumah \& Solihin, 2003:8) adalah desa atau yang disebut dengan nama lain sebagai suatu kesatuan masyarakat hukum yang mempunyai susunan asli berdasarkan hak asal usul yang bersifat istimewa, sebagaimana yang dimaksud dalam penjelasan Pasal 18 Undangundang Dasar 1945. Landasan pemikiran dalam pengaturan mengenai Pemerintah Desa adalah keanekaragaman, partisipasi, otonomi asli, demokratis, dan pemberdayaan masyarakat

Selanjutnya menurut Peraturan Pemerintah No. 60 Tahun 2014 dikatakan bahwa Desa Desa adalah Desa dan Desa adat atau yang disebut dengan nama lain, selanjutnya disebut Desa adalah kesatuan masyarakat hukum yang memiliki batas wilayah yang berwenang untuk mengatur dan mengurus urusan pemerintahan, kepentingan masyarakat setempat berdasarkan prakarsa masyarakat, hak asal usul, dan/atau hak tradisional yang diakui dan dihormati dalam sistem pemerintahan Negara Kesatuan Republik Indonesia.

\section{B. Konsep Dana Desa dan Alokasi Dana Desa (ADD)}

Menurut Sutoro Eko, Anom Surya Putra, Maizir Akhmadin, Suhirman, Hadi Prayitno, Nana Suryana, Zaini Mustakim (2016: 1) Dana Desa (DD) adalah dana yang bersumber dari APBN yang diperuntukkan bagi Desa dan ditransfer melalui APBD Kabupaten/Kota setiap tahun, untuk membiayai penyelenggaraan 
kewenangan Desa berdasarkan hak asal usul, dan kewenangan lokal skala Desa.

Dana desa sendiri diperoleh setiap tahun Desa akan mendapatkan Dana Desa (DD) dari Pemerintah Pusat yang penyalurannya dilakukan melalui kabupaten/kota. Dana Desa merupakan mandat UU No. 6 Tahun 2014 tentang Desa, dialokasikan dalam bentuk transfer, bukan berbentuk proyek. Selama UU Desa berlaku maka DD akan terus menerus dialokasikan oleh Pemerintah.

\section{Kedudukan dan Fungsi Dana Desa}

Dana Desa merupakan pendapatan utama. Dana Desa dapat digunakan untuk membiayai program dan kegiatan prioritas yang telah disepakati dan ditetapkan di dalam musyawarah perencanaan pembangunan Desa (Musrenbang Desa) tentang Rencana Kerja Pemerintah Desa (RKP Desa) setiap tahun. Penggunaan Dana Desa secara swakelola atau padat karya adalah untuk penyerapan tenaga kerja di Desa, khususnya warga miskin, serta penyediaan sarana dan prasarana dasar Desa, seperti jalan lingkungan, jalan usaha tani, jembatan, dan saluran irigasi.

Menurut UU No. 6 Tahun 2014 dana desa adalah dana yang bersumber dari anggaran pendapatan dan belanja negara yang diperuntukkan bagi desa yang ditransfer melalui anggaran pendapatan dan belanja daerah kabupaten/kota dan digunakan untuk membiayai penyelenggaraan pemerintahan, pelaksanaan, pembangunan, pembinaan kemasyarakatan, dan pemberdayaan masyarakat.

Tujuan adanya ADD dalam Peraturan Menteri Dalam Negeri Nomor 37 Tahun 2007 tentang Pedoman Pengelolaan Keuangan Desa, adalah:

1. Menanggulangi kemiskinan dan mengurangi kesenjangan;

2. Meningkatkan perencanaan dan penganggaran pembangunan di tingkat desa dan pemberdayaan masyarakat;

3. Meningkatkan pembangunan infrastruktur perdesaan.;

4. Meningkatkan pengamalan nilai - nilai keagamaan, sosial budaya dalam rangka mewujudkan peningkatan sosial;
5. Meningkatkan ketentraman dan ketertiban masyarakat;

6. Meningkatkan pelayanan pada masyarakat desa dalam rangka pengembangan kegiatan sosial dan ekonomi masyarakat;

7. Mendorong peningkatan keswadayaan dan gotong royong masyarakat;

8. Meningkatkan pendapatan desa dan masyarakat desa melalui Badan Usaha Milik Desa (BUMDesa).

\section{Pengelolaan Alokasi Dana Desa}

Pengelolaan Keuangan Alokasi Dana Desa (ADD) merupakan bagian yang tidak terpisahkan dari Pengelolaan Keuangan Desa dalam APBDesa oleh karena itu dalam Pengelolaan Keuangan Alokasi Dana esa (ADD) harus memenuhi Prinsip Pengelolaan Alokasi Dana Desa sebagai berikut:

a. Seluruh kegiatan yang didanai oleh Alokasi Dana Desa (ADD) direncanakan, dilaksanakan dan dievaluasi secara terbuka dengan prinsip dari, oleh dan untuk masyarakat.

b. Seluruh kegiatan harus dapat dipertanggungjawabkan secara administrative, teknis dan hukum.

c. Alokasi Dana Desa (ADD) dilaksanakan dengan menggunakan prinsip hemat, terarah dan terkendali.

d. Jenis kegiatan yang akan dibiayai melalui Alokasi Dana Desa (ADD) sangat terbuka untuk meningkatkan sarana pelayanan masyarakat berupa pemenuhan kebutuhan dasar, penguatan kelembagaan desa dan kegiatan lainnya yang dibutuhkan masyarakat desa yang diputuskan melalui musyawarah desa.

e. Alokasi Dana Desa (ADD) harus dicatat dalam Anggaran Pendapatan dan Belanja Desa (APBDesa) dan proses penganggarannya mengikuti mekanisme yang berlaku.

\section{E. Pemberdayaan Masyarakat}

Menurut Wahjudin Sumpeno (2011:19) pemberdayaan adalah upaya yang dilakukan oleh unsure yang berasal dari luar tatanan terhadap suatu tatanan, agar tatanan trsebut mampu berkembang secara mandiri, dengan 
kata lain pemberdayaan sebagai upaya perbaikan wujud interkoneksitas yang terdapat di dalam suatu tatanan dan atau penyempurnaan terhadap elemen atau komponen tatanan yang ditujukan agar tatanan dapat berkembang secara mandiri.

\section{METODE PENELITIAN}

Berdasarkan tujuan penelitian yang ingin dicapai yaitu untuk mengetahui permasalahan bagaimana pengelolaan alokasi dana desa (ADD) dalam hal ini keterkaitan dengan pemberdayaan ekonomi produktif masyarakat di desa maka penelitian ini dilakukan melalui pendekatan deskriptif kualitatif.

Fokus penelitian ini adalah bagaimana perencanaan, pelaksanaan, dan pelaporan pertanggungjawaban ADD. Pemerintah mengeluarkan peraturan pemerintahan Republik Indonesia Nomor 43 Tahun 2014 tentang peraturan pelaksanaan Undang-Undang Nomor 6 Tahun 2014 tentang desa. Pemerintah daerah mempunyai kewenangan yang lebih luas dalam pengelolaan daerahnya.

Objek dalam penelitian ini Kabupaten Bone Bolango yang terdiri dari 160 Desa dan 5 Kelurahan. Pemilihan objek berupa Desa untuk melihat bagaimana perbedaan dari beberapa desa dalam satu kecamatan dalam mengelolaa Alokasi Dana Desa (ADD) dalam rangka pemberdayaan ekonomi produktif yang ada di Masyarakat Desa.

\section{HASIL DAN PEMBAHASAN 1. Dana Desa Dan Alokasi Dana Desa Tahun 2017}

Sumber pendapatan desa atau biasa dikenal dengan APBDes di kategorikan dari beberapa pendapatan yakni: 1). sumber yang berasal dari APBN yang diperuntukkan untuk desa (dana desa) yang ditransfer langsung melalui APBD Kabupaten/ Kota; 2). Alokasi Dana Desa (ADD) yang berasal dari Kabupaten/ Kota yang merupakan Dana Bagi Hasil (DBH) dan Dana Alokasi Umum (DAU) yang merupakan bagian Dana Perimbangan.

Berikut adalah tabel pembagian Dana Desa (DD) Dan Alokasi Dana Desa (ADD) Tahun 2017 sekabupaten Bone Bolango seperti yang tertuang dalam tabel berikut ini:

Tabel 1

Pembagian Dana Desa (DD) Dan Alokasi Dana Desa (ADD) Tahun 2017 Se-kabupaten Bone Bolango

\begin{tabular}{|c|c|c|c|c|c|}
\hline No & Kecamatan & Pagu DD & Pagu ADD & $\begin{array}{c}\text { Pagu ADD } \\
\text { Afirmatif }\end{array}$ & Total \\
\hline 1 & Tapa & $5,332,740,000$ & $2,113,251,000$ & & $7,445,991,000$ \\
\hline 2 & Kabila & $5,330,520,000$ & $2,108,145,000$ & & $7,438,665,000$ \\
\hline 3 & Suwawa & $7,621,352,000$ & $3,008,718,000$ & & $10,630,070,000$ \\
\hline 4 & Bone Pantai & $9,982,737,000$. & $3,985,881,000$ & & $13,968,618,000$ \\
\hline 5 & Bulango Utara & $6,866,424,000$ & $2,711,931,000$ & & $9,578,355,000$ \\
\hline 6 & Tilongkabila & $10,718,446,000$ & $4,257,138,000$ & & $14,975,584,000$ \\
\hline 7 & Botupingge & $6,730,321,000$ & $2,640,447,000$ & & $9,370,768,000$ \\
\hline 8 & Kabila Bone & $7,046,338,000$ & $2,860,005,000$ & 488.250 .000 & $10,394,593,000$ \\
\hline 9 & Bone & $10,733,449,000$ & $4,241,820,000$ & & $14,975,269,000$ \\
\hline 10 & Bone Raya & $7,576,269,000$ & $2,983,188,000$ & & $10,559,457,000$ \\
\hline 11 & Suwawa Timur & $6,834,360,000$ & $2,691,507,000$ & $488,250,000$ & $10,014,117,000$ \\
\hline 12 & Suwawa Selatan & $6,146,537,000$ & $2,450,886,000$ & & $8,597,423,000$ \\
\hline 13 & Suwawa Tengah & $4,553,635,000$ & $1,796,040,000$ & & $6,349,675,000$ \\
\hline 14 & Bulango Ulu & $4,626,776,000$ & $1,811,358,000$ & $976,500,000$ & $7,414,634,000$ \\
\hline 15 & Bulango Selatan & $7,725,521,000$ & $3,064,884,000$ & & $10,790,405,000$ \\
\hline
\end{tabular}




\begin{tabular}{|c|c|c|c|c|c|}
\hline 16 & Bulango Timur & $3,790,462,000$ & $1,494,147,000$ & & $5,284,609,000$ \\
\hline 17 & Bulawa & $6,824,388,000$ & $2,706,825,000$ & & $9,531,213,000$ \\
\hline 18 & Pinogu & $3,894,228,000$ & $1,580,999,620$ & $600,008,980$ & $6,075,236,600$ \\
\hline & Jumlah & $\mathbf{1 2 2 , 3 3 4 , 5 0 3 , 0 0 0}$ & $\mathbf{4 8 , 5 0 7 , 1 7 0 , 6 2 0}$ & $\mathbf{2 , 5 5 3 , 0 0 8 , 9 8 0}$ & $\mathbf{1 7 3 , 3 9 4 , 6 8 2 , 6 0 0}$ \\
\hline
\end{tabular}

Sumber Data: Dinas Pemberdayaan dan Pemerintah Desa. 2017

Jika dilihat pada uraian tabel 5.2 maka dapat disimpulkan bahwa total dana yang dikelola oleh setiap desa yang ada di Kabupaten Bone Bolango dapat dirata-ratakan berjumlah $\mathrm{Rp}$. 1.000.000.000,-. Dengan demikian jumlah dana yang dikelola dimasing-masing desa tidak ada dibawah dari Rp. 1.000.000.000.

\section{Pengelolaan Dana Desa (DD) / Alokasi Dana Desa (ADD) \\ Perencanaan Dana Desa (DD) / Alokasi Dana Desa (ADD)}

Pengelolaan Dana Desa (DD) proses selama ini diawali dengan proses perencanaan. Proses perencanaan sendiri tentunya melalui aspirasi dari tingkat bawah. Hal ini dilakukan dalam rangka untuk menjaring lebih banyak apa sebenarnya yang menjadi kebutuhan masyarakat.

Proses perencanaan Diawali dengan musyawarah/ pertemuan yang dilakukan ditingkat desa berupa penyusunan RPJMDes, selanjutnya dilanjutkan ke Rencana Kerja Pembangunan Desa (RKPDes) yang kemudian ditindak lajuti dalam proses penyusunan Anggaran Pendapatan Belanja Desa (APBDes) yang kesemuanya perlu dilindungi dengan payung hukum berupa regulasi-regulasi yang dibuat oleh pemerintah Desa. Dengan demikian proses perencanaan ini memenuhi unsur partisipatif masyarakat desa.

Sebagaimana yang dikemukakan oleh Adisasmita (2006:28) bahwa proses perencanaan partisipatif dalam menyusun program pembangunan harus dilakukan melalui analisis permasalahan, analisis potensi, dan analisis kepentingan kelompok dalam masyarakat, dengan menggunakan kriteriayang terukur sehingga menghasilkan rumusan program pembangunan yang benar-benar dibutuhkan oleh masyarakat setempat. Jadi perencanaan dilakukan secara buttom-up (dari lapisan masyarakat grass root) dan menggunakan pendekatan partisipatif dan spasial.

\section{Pengangaran Dana Desa (DD)}

Proses penganggaran Dana Desa (DD) sendiri dilakukan setelah hasil dari musyawarah desa disetujui oleh seluruh pihak yang terkait di desa, sehingga dapat disusun Rencana Penggunaan Dana (RPD) selama satu tahun berjalan. Berdasarkan hasil wawancara peneliti dengan beberapa informan, dalam hal ini para kepala desa terlihat dana peruntukkan khusus pemberdayaan masyarakat dan penguatan kapasitas pemerintah serta biaya operasional pemerintah desa dan Badan Permusyawaratan Desa terjadi perbedaan dan justru tidak seragam. Hal ini merupakan hasil dari Musyawarah yang dilakukan pertama kali di tingkat desa.

Jika dilihat dari sisi pembagian anggaran khusus pemberdayaan dan penguatan kapasitas pemerintah desa jauh lebih besar dibandingkan dari dana biaya operasional Pemerintah desa dan BPD dikarenakan penganggaran pilihan prioritas jatuh pada pembangunan Desa dan pemberdayaan masyarakat Desa didasari oleh beberapa pertimbangan dan alasan.

Menurut (Sutoro Eko dkk, 2016:18) Pertama, penggunaan Dana Desa untuk pembangunan Desa dan pemberdayaan masyarakat Desa pada dasarnya menjadi bagian dari dimensi pemerataan dalam pembangunan nasional, agar Dana Desa menyentuh langsung kepada kepentingan masyarakat setempat, untuk tujuan pengurangan kemiskinan dan ketimpangan. Kedua, prioritas Dana Desa disesuaikan dengan prioritas nasional yang tertuang dalam NAWACITA, yakni infrastruktur, pangan dan energi, sekaligus juga penguatan Desa dalam rangka membangun Indonesia dari pinggiran. Ketiga, Pemerintah membina dan memberdayakan Desa agar para pemangku Desa tidak terjebak pada aspek administrasi pemerintahan Desa yang sempit, 
melainkan Desa mempunyai peran (emansipasi) dalam memberikan manfaat nyata kepada masyarakat melalui pembangunan dan pemberdayaan.

\section{Pencairan Dana Desa (DD)}

Proses pencairan dan penyaluran dana desa (DD) dan alokasi dana desa (ADD), secara teknis pada prinsipnya sama. Proses ini diawali dari tingkat desa, dimana pemerintah desa melalui Bendahara desa harus melengkapi semua berkas yang akan dijadikan sebagai berkas pengajuan dana desa. Setelah semua berkas pengajuan DD maupun ADD lengkap baru kemudian diajukan ke kantor camat untuk diverifikasi tahap awal. Jika berkas tersebut sudah benar dan lengkap kemudian diajukan ke Dinas Pemberdayaan dan Pemerintah Desa (DMPD) mengetahui camat. Kemudian Dinas Pemberdayaan dan Pemerintah Desa akan meneruskan berkas permohonan berikut lampirannya kepada Kepala Dinas Pendapatan, Pengelolaan Keuangan dan Asset (DPPKA). Apabila semua persyaratan sudah dipenuhi maka DPPKA segera mentransfer dana desa (DD) maupun Alokasi Dana Desa (ADD) ke rekening masing-masing desa.
Hal diatas dijelaskan oleh Ibu Anisa Hubulo, SE (Bendahara Desa Talulobutu Selatan), berikut kutipan wawancaranya.

"Untuk pengajuan dana desa maupun alokasi dana desa, kami perangkat desa mempersiapkan semua berkas terkait dengan pencairan dana tersebut. setelah itu kami ajukan ke tingkat Kecamatan untuk diverifikasi. setelah itu pihak kecamatan akan meneruskan ke Dinas Pemberdayaan dan PEMDES untuk diverikasi lanjutan untuk kemudian akan diteruskan ke Dina Pendapatan Daerah. nah disana kalau sudah lengkap dan memenuhi syarat tinggal menunggu Surat perintah pembayaran. disitu torang tinggal tunggu di rekening saat itu juga

Berikut Alur mekanisme pencairan/ penyaluran dan pencairan DD \& ADD disetiap desa sesuai dengan peraturan yang mengatur pengelolaan keuangan desa yaitu Peraturan Menteri Dalam Negeri Nomor 37 Tahun 2007 tentang Pedoman Pengelolaan Keuangan Desa

\section{Gambar 1 \\ Alur mekanisme pencairan/ penyaluran Dana Desa \& Alokasi Dana Desa}

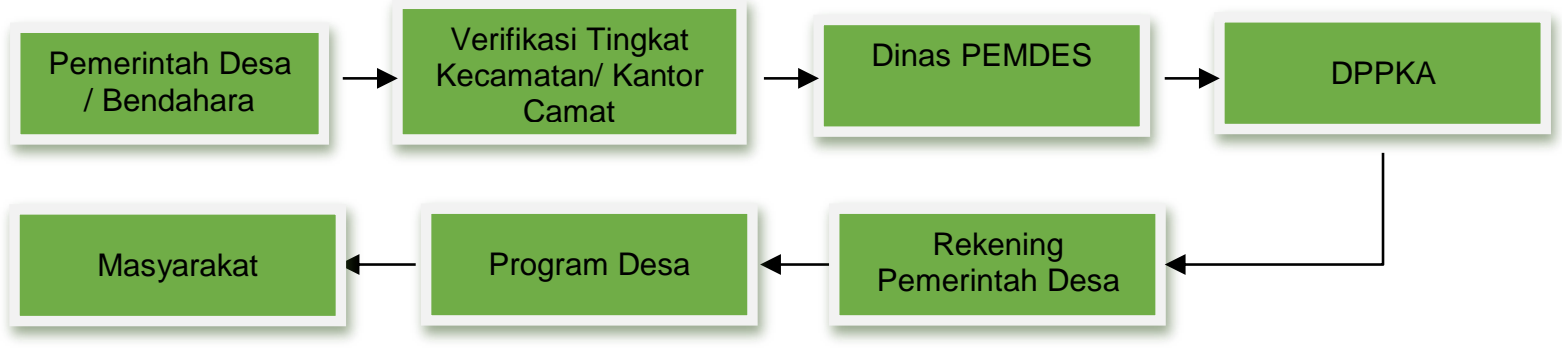

\section{Penggunaan Dana Desa (DD) \& Alokasi Dana Desa (ADD)}

Berdasarkan Undang-Undang Nomor 6 Tahun 2014 tentang Desa, Desa mempunyai kewenangan untuk mengatur dan mengurus bidang penyelenggaraan pemerintahan Desa, pelaksanaan pembangunan Desa, pemberdayaan masyarakat Desa dan pembinaan kemasyarakatan Desa. Hal itu berarti seluruh sumber pendapatan Desa, termasuk Dana Desa yang bersumber dari APBN, digunakan untuk mendanai keseluruhan kewenangan Desa. Namun, sesuai dengan Peraturan Pemerintah No. 60/2014, mengingat Dana Desa bersumber dari Belanja Pusat, untuk mengoptimalkan penggunaan Dana Desa, Pemerintah diberikan kewenangan untuk menetapkan prioritas penggunaan Dana Desa untuk mendukung 
pembangunan Desa dan pemberdayaan masyarakat Desa. Penetapan prioritas penggunaan dana tersebut tetap sejalan dengan kewenangan yang menjadi tanggung jawab Desa.

Secara khusus penggunaan alokasi dana desa (ADD) terbagi menjadi 2 (dua), yaitu untuk penyelenggaraan pemerintahan desa dan untuk pemberdayaan masyarakat. ADD yang dialokasikan untuk penyelenggaraan pemerintahan desa digunakan untuk Tunjangan Aparat pemerintah desa (TAPDes), operasional pemerintah desa, dan operasional Badan Permusyawaratan Desa. Sedangkan ADD yang dialokasikan untuk pemberdayaan masyarakat digunakan untuk pembangunan/ pemeliharaan sarana prasarana fasilitas umum, penguatan kapasitas lembaga kemasyarakatan desa, penguatan ekonomi desa, dan bantuan pembentukan BPD dan pemilihan Kepala Desa.

Berdasarkan uraian di atas maka guna memaksimalkan anggaran dana desa (DD) maupun dana alokasi dana desa (ADD) dalam pelaksanaan program pemberdayaan maka khusus daerah Kabupaten Bone Bolango program - program pemberdayaan masyarakat yang dibiayai melalui kedua dana tersebut adalah sebagai berikut:

1. Usaha Peternakan Sapi

Bantuan dibidang peternakan adalah Bantuan sapi. Setiap rumah tangga miskin berhak mendapatkan 2 ekor sapi yang nantinya di tahun kedua digilir pada keluarga miskin lainnya. Disamping bantuan sapi juga diberikan bantuan bibit ayam kampung.

2. Usaha Karang Taruna

Bantuan bagi karang taruna dalam bantuan permodalan peralatan perbengkelan dan lain-lain.

3. Bantuan Usaha Pertanian Jenis bantuan pertanian adalah pengadaan bibit jagung dan varitas padi unggulan juga termasuk bantuan pupuk.

4. Bantuan Usaha Perikanan

Dibidang usaha perikanan sendiri jenis bantuannya adalah kapal katintang dan alat penangkapan ikan. khusus ikan tawar diberikan bantuan pengadaan bibit ikan nila, lele dan Udang.
5. Bantuan Usaha Industri

Khusus usaha industri adalah bantuan modal peralatan usaha.

6. Bantuan Usaha Kel. Perempuan

Khusus bantuan bagi ibu - ibu/ kaum perempuan adalah pengadaan bibit jahe, Bibit cabe, juga bantuan pengadaan bahanbahan jualan untuk kios dan sebagainya.

Disamping jenis bantuan di atas, maka untuk memaksimalkan program tersebut maka setiap bantuan tersebut melalui pembiayaan dana desa dan alokasi dana desa juga dilakukan program pelatihan dan pendampingan terkait program diatas. Misalnya bagi penerima bantuan pengadaan bibit sapi dan ayam diberikan pelatihan bagaimana membuat pakan hewan yang baik.

Dalam penggunaan dana desa (DD) dan alokasi dana desa (ADD) ada beberapa hal yang menjadi perhatian dalam hal penggunaan dana tersebut, dengan kata lain bahwa ada beberapa kegiatan pembiayaan yang tidak dibenarkan/ dilarang penggunaannya melalui dana desa (DD) seperti tunjangan para aparat desa, perjalanan dinas, pembangunan dan renovasi kantor desa, dan pengadaan Moubelair kantor desa. khusus pemberdayaan sendiri kegiatan seperti program PKK, honor para imam mesjid dan penjaga mesjid tidak dapat dibiayai melalui dana desa (DD). Sihingganya kegiatan yang tidak bisa dibiayai melalui dana desa (DD) dapat dialokasikan melalui pembiayaan alokasi dana desa (ADD).

Guna memaksimalkan penggunaan dana desa dalam bentuk bantuan mdal bagi IKM / pelaku usaha oleh Dinas Pemberdayaan dan Pemerintah Desa sesuai dengan sasaran strategis yang dirumuskan, maka pengembangan perekonomian masyarakat desa diarahkan serta diwujudkan melalui program PROKADES (Produk unggulan kawasan pedesaan), melalui pengembangan SUDA SAPU (satu desa satu produk unggulan) atau biasa dikenal dengan OVOP (One Village One Product).

Perwujudan hasil dari program tersebut dapat dilihat pada beberapa produk unggulan yang dihasilkan oleh masing-masing desa. Misalnya Desa Mongiilo terkenal dengan produknya Gula Aren/ Merah \& Gula Semutnya, Desa Pinogu dikenal dengan Kopi Pinogu, Desa 
Panggula dengan Produk Kue Ceruti, Desa Tupa dikenal dengan Produk madunya dan produk desa lainnya.

\section{Pengawasan/ Evaluasi Dana Desa (DD)}

Untuk skala lokal Desa, UU Desa menegaskan hak Badan Permusyawaratan Desa (BPD) untuk mengawasi dan meminta keterangan tentang penyelenggaraan Pemerintahan Desa kepada Pemerintah Desa, termasuk didalamnya adalah aliran penggunaan DD. Pengawasan aliran DD yang dilakukan oleh BPD cukup membahas hal strategis penggunaan DD dalam mengatasi masalah di Desa

Hal di atas dijelaskan oleh Bapak Mahdi Yusuf (Ketua BPD Desa Talulobutu Selatan). Dalam dialognya dengan peneliti beliau menjelaskan bahwa pihak BPD bukan saja hanya melakukan pengawasan akan tetapi juga wajib mendorong pemerintah desa juga bertanggung jawab akan pengelolaan dan penyaluran dana desa. Berikut kutipan wawancara tersebut.

"Kami selaku BPD memang harus dilibatkan dalam sistim pengawasan, keterlibatan ini merupakan tanggung jawab kami untuk menjalankannya dengan baik. Sebab dalam setiap pengusulan anggaran tersebut kami selaku pengurus BPD di desa juga turut serta menandatangani pengajuan dana desa".

Keterlibatan masyarakat juga sangat diharapkan melakukan pengawasan secara partisipatif terhadap penggunaan DD, antara lain melakukan pengawasan secara partisipatif tehradap pelaksanaan Pembangunan Desa dibandingkan dengan isi Peraturan Desa yang telah diterbitkan. Masyarakat juga berhak mendapatkan informasi tentang pelaksanaan kegiatan yang menggunakan DD

Selanjutnya untuk menghidari hal-hal yang tidak diinginkan seperti penyelewengan anggaran desa maka Keuangan Desa termasuk di dalamnya Dana Desa oleh desa dikelola oleh Tim yaitu perangkat Desa yang terdiri dari Kepala Desa, Sekretaris Desa, Kepala Urusan, dan Bendahara Desa, yang masing-masing memiliki kewenangan, tugas dan tanggungjawab yang berbeda, sebagaimana diatur dalam Peraturan Menteri Dalam Negeri Nomor 113/2015 tentang Pengelolaan Keuangan Desa. Hal ini dilakukan guna menjamin pengendalian keuangan Desa tidak berada dalam "satu tangan", tetapi berada dalam satu tim, dengan sistem kelola yang diharapkan dapat menjamin dari terjadinya penyimpangan.

\section{PertanggungJawaban}

Pemerintah Desa (Kepala Desa dan Perangkat Desa) berkewajiban menyusun laporan pertanggungjawaban kepala Desa setiap akhir tahun anggaran. Pertanggungjawaban disampaikan dalam forum Musyawarah Desa sekaligus sebagai forum musyawarah untuk merencanakan pembangunan tahun yang akan datang.

Untuk pertanggungjawaban pengelolaan dana desa maupun alokasi dana desa sebagaimana wawancara dengan Ibu Indrawaty Lasia (Kepala Desa Lomaya) sebagai berikut:

"Proses pertanggungjawaban dilakukan pada saat setiap atau per kegiatan dalam bentuk dokumentasi dan dokumen laporan. selanjutnya dilaporkan ke pihak BPMD dan laopran pertanggung jawaban kepala desa disampaikan ke BPD dan Bupati". (Wawancara, 18 Agustus 2017)

Mencermati uraian di atas maka Informasi-informasi tersebut dapat dikategorikan bahwa sistem pertanggung jawaban pelaksanaan program ADD di di setiap desa yang ada di lingkungan Kab. Bone Bolango telah menerapkan prinsip akuntabilitas, khususnya dalam hal sistem pengadministrasian pertanggungjawaban keuangan ADD

\section{Model Pengelolaan Dana Desa (DD) \& Alokasi Dana Desa (ADD) di Desa}


Gambar 5.3

Model Pengelolaan Dana Desa (DD) \& Alokasi Dana Desa (ADD) di Desa

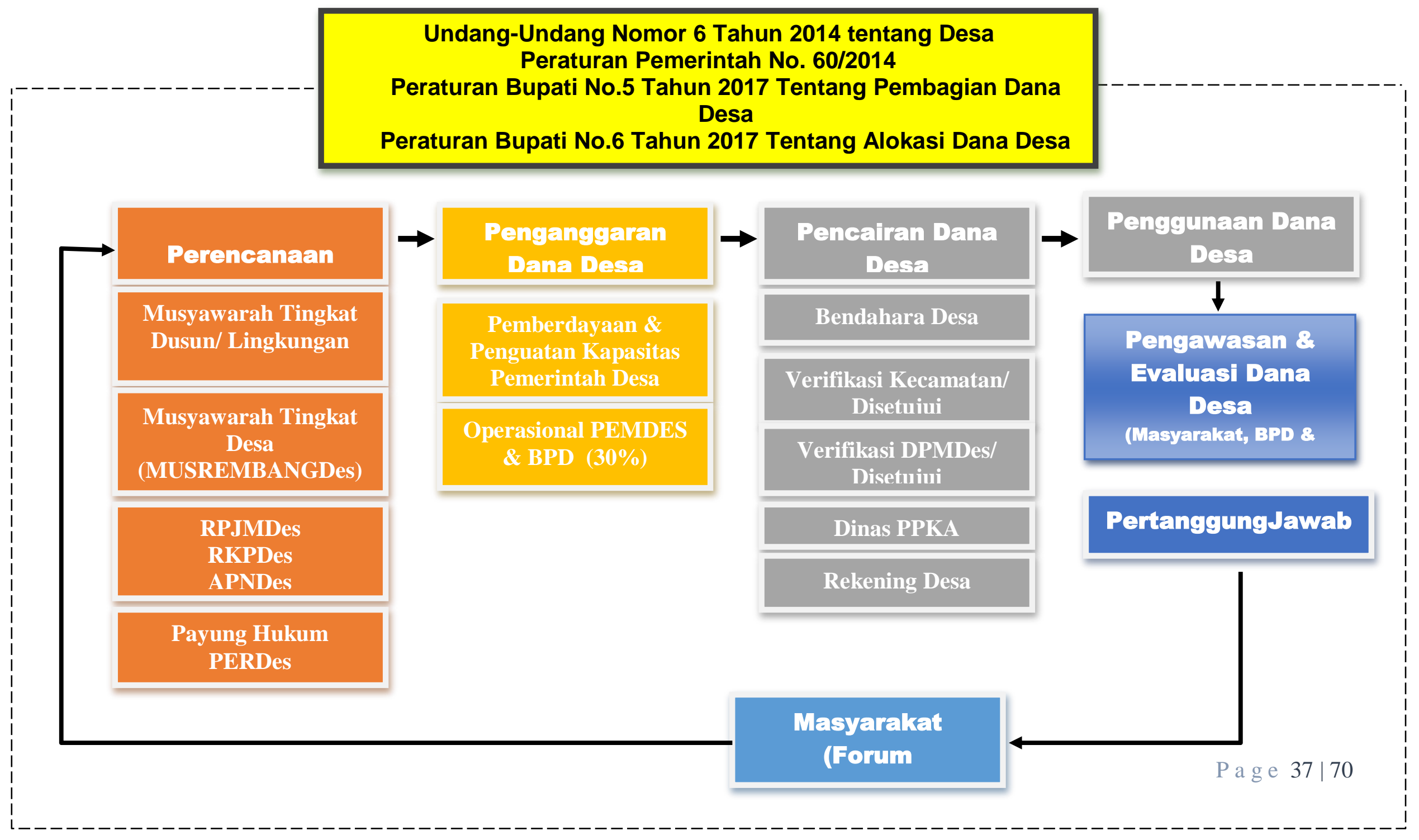




\section{KESIMPULAN}

1. Dana desa yang diberikan oleh pemerintah pusat ke desa-desa terbukti ampuh mensejahterakan masyarakat. Hal tersebut bisa dilihat dari berbagai capaian yang dilakukan oleh Pemerintah Kabupaten Bone Bolango. Keberhasilan dana desa dalam mensejahterakan masyarakat, membuat pemerintah pusat terus meningkatkan jumlah alokasi anggaran dana desa setiap tahunnya.

2. Anggaran Dana Desa Tahun 2017 Rp. 122.344.494.000

3. Fakta membuktikan bahwa Dana Desa mampu menjadi daya ungkit terhadap perekonomian desa untuk berkembang maju dan meningkatkan kesejahteraan masyarakat di kabupaten bone bolango

4. Dengan Dana Desa digunakan untuk pembangunan infrastruktur desa dan pemberdayaan masyarakat desa yang padat karya, mampu menyerap banyak warga desa untuk ikut bekerja, mereka mendapat upah, bisa membeli kebutuhan pokok di warung-warung desa, inilah yang mendorong sektor konsumsi rumah tangga untuk bergerak, yang kemudian ikut pula menggerakkan roda perekonomian daerah sehingga dapat menurunkan angka kemiskinan masyarakat di Kabupaten Bone Bolango.

\section{DAFTAR PUSTAKA}

Adisasmita, Rahardjo 2006. Membangun Desa Partisipasi. Graha Ilmu. Yogyakarta

Badan Pemberdayaan Masyarakat Dan Pemerintahan Desa. 2014. Pedoman umum dan petunjuk teknis pelaksanaan alokasi dana desa (ADD). Selatpanjang

Bratakusumah, Dedi Supriyadi \& Dadang Solihin. 2003. Otonomi Penyelenggaraan Pemerintah Daerah. PT. Gramedia Pustaka Utama. Jakarta

Darmiasih, dkk. 2015. Analisis Mekanisme Penyaluran Alokasi Dana Desa (ADD)ada Pemerintah Desa (Studi Kasus Desa Tri Buana Kecamatan Sidemen.Kabupaten Karangasem). Jurusan Akuntansi Universitas Pendidikan Ganesha. Volume 1 No. 3 Tahun 2015.

Faridah. 2015. Transparansi dan Akuntabilitas Pemerintah Desa dalam Pengelolaan
Anggaran Pendapatan dan Belanja Desa (APBDES). Sekolah Tinggi Ilmu

Kartasasmita, G. 1996. Pembangunan untuk Rakyat, Memadukan Pertumbuhan dan Pemerataan. Jakarta : CIDES.

Moleong, Lexi. 2007. Metode Penelitian Kualitatif. Edisi Revisi. Cetakan Kedua Puluh Tiga. PT. Remaja Rosdakarya. Bandung

Nurcholis, Hanif. 2011. Pertumbuhan \& Penyelenggaraan Pemerintahan Desa. Jakarta: Penerbit Erlangga

Republik Indonesia. 2014. Undang-Undang Nomor 6 Tahun 2014 Tentang Desa, Pasal 72 ayat (1) point (d), dan butir (4), op.cit, h. 41

Republik Indonesia. 2005. Peraturan Pemerintah Republik Indonesia Nomor 72 Tahun 2005, $\quad$ Pasal 68 ayat. Tentang Desa

Peraturan Pemerintah Republik Indonesia Nomor 60 Tahun 2014 Tentang Dana Desa Yang Bersumber Dari Anggaran Pendapatan Dan Belanja Negara

2007. Peraturan Menteri Dalam Negeri Nomor 37 Tahun 2007 Tentang Pedoman Pengelolaan

Keuangan Desa, Pasal 18.

Sahdan, Gorris dkk. 2004. Buku Saku Pedoman Alokasi Dana Desa. Bandung : FPPD.

Strauss, Anselm dan Juliet Corbin. 2009.

Dasar-Dasar Penelitian Kualitatif. Cetakan Ke Tiga. Pustaka Pelajar. Yogyakarta.

Sugiyono, 2009, Memahami Penelitian Kualitatif, Alfabeta, Bandung

Sutoro Eko, Anom Surya Putra, Maizir Akhmadin, Suhirman, Hadi Prayitno, Nana Suryana, Zaini Mustakim. 2016. Dana Desa Untuk Desa Membangun Indonesia (Tanya Jawab Seputar Dana Desa). Kementerian Desa, Pembangunan Daerah Tertinggal, dan Transmigrasi Republik Indonesia. Cetakan Pertama: Jakarta

Sumaryadi, I Nyoman (2005) Perencanaan

Pembangunan Daerah Otonom dan Pemberdayaan Masyarakat. Jakarta,Citra Utama.

Tjokroamidjojo, Bintoro, 2000, Good Governance (Paradigma Baru Manajemen Pembangunan), UI Press, Jakarta 
Wahjudin, Sumpeno. 2011. Perencanaan Desa Terpadu. Banda Aceh,Reinforcement Action and Development 